МОНГОЛОВЕДЕНИЕ

(Монгол судлал)

(Mongolian Studies) (Elista)

Vol. 12, Is. 3, pp. 446-454, 2020

DOI: 10.22162/2500-1523-2020-3-446-454
ISSN 2500-1523 (Print)

ISSN 2712-8059 (Online)

Published since 2002

https://mongoloved.kigiran.com/jour

\title{
Дал шинжилгээний уламжлал бэлгэдэл (Шинжааны Баянголын монголчуудын жишээгээр) (= Традиция гадания на бараньей лопатке и его символика (на примере баянгольских монголов Синьцяна))
}

\author{
Гомбожав ${ }^{1}$ \\ ${ }^{1}$ Северо-Западный университет национальностей \\ (д. 1, Северо-Западная Нью Виллидж, г. Ланьчжоу 730030, Ганьсу, КНР) \\ аспирант \\ (iD) 0000-0002-4998-4085. E-mail: 417433512@qq.com \\ (C) КалмНЦ РАН, 2020 \\ (C) Гомбожав, 2020
}

\begin{abstract}
Аннотация. Введение. В культурной традиции монгольских народов существуют обычаи сакрализации определенных частей костей животных и связанные с ними обрядовые действия и запреты. Особо выделяется в этой традиции древний обряд сказывания и гадания на бараньей лопатке. Цель статьи - осветить традицию гадания на бараньей лопатке, бытующую среди баянгольских монголов (ойратов) СУАР КНР. Результаты. Лопатка как важная и сакральная часть тела упоминается во многих устных и письменных произведениях ойратских народов, в том числе и в древнейшем письменном памятнике «Сокровенное сказание монголов» и эпосе «Джангар». В пищевой культуре ойратов существует особая традиция подношения бараньей лопатки определенным по возрасту и социальному положению членам семьи и рода. В тексте благопожелания, которое произносится после поедания лопаточного мяса и обязательного надламывания лопаточной кости, а также в тексте сказывания и гадания на бараньей лопатке присутствуют определенные общие трафаретные формулы, имеющие глубокое символическое значение. В статье рассмотрены существующие в традиции ойратов Баянгол-Монгольского автономного округа СУАР КНР обряды, связанные со сказыванием и гаданием на бараньей лопатке, а также символический смысл текста сказывания и благопожелания.
\end{abstract}

Ключевые слова: лопаточная кость, традиция, обряд гадания и сказывания, символика текста

Благодарность. Материалы статьи апробированы на Международной научной онлайн-конференции «Монголоведение в начале XXI в.: современное состояние и перспективы развития-ІІ», проведенной при финансовой поддержке РФФИ (проект № 2009-22004) и частичной поддержке гранта Правительства РФ (№ 075-15-2019-1879).

Для цитирования: Гомбожав. Дал шинжилгээний уламжлал бэлгэдэл (Шинжааны Баянголын монголчуудын жишээгээр) (= Традиция гадания на бараньей лопатке и его 
символика (на примере баянгольских монголов Синьцзяна)) // Монголоведение. 2020. T. 12. № 3. С. 446-454. (На монг.). DOI: 10.22162/2500-1523-2020-3-446-454

UDC 398.5

DOI: $10.22162 / 2500-1523-2020-3-446-454$

\title{
Tradition and Symbolism of Sheep Scapula Divination: a Case Study of Bayangol Mongols from Xinjiang
}

\section{Gongmujafu (Gombojav) ${ }^{1}$}

\author{
${ }^{1}$ Northwest University for Nationalities (1, Northwest New Village, Minying Rd., Chengguan, \\ Lanzhou 730030, Gansu, People's Republic of China) \\ postgraduate student
} (iD) 0000-0002-4998-4085. E-mail: 417433512@qq.com

\author{
(C) KalmSC RAS, 2020 \\ (C) Gongmujafu, 2020
}

\begin{abstract}
Introduction. In the cultural tradition of Mongolic peoples, there is a rite of sacralizing certain parts of animal bones, and related ritual actions and prohibitions. In this regard, a special place is held by the ancient rite of telling tales and divination on sheep scapula. Goals. The paper seeks to examine the mentioned practice among Bayangol Mongols (Oirats) of the Xinjiang Uighur Autonomous Region (PRC). Results. The shoulder bone as an important and sacred part of the body is mentioned in many oral and written narratives, including such ancient written monuments as The Secret History of the Mongols and the Epic of Jangar. In the food culture of the Oirats, there is a special tradition of offering a shoulder bone to certain members of the family and clan, by age and social status. In the verse of benevolence to be recited after eating the spatula meat and an obligatory break of the scapula, as well as in the text of the narrative and divination on sheep scapula, there are certain general clichéd formulas that have a deep symbolic meaning. The article examines the rites that exist in the tradition of the Oirats of Bayangol related to storytelling and divination on sheep scapula, as well as the symbolic meaning of the texts.
\end{abstract}

Keywords: scapula, tradition, divination and storytelling rite, symbolism of text

Acknowledgements: The article was presented at the international scientific online conference "Mongolian Studies at the beginning of the 21st century: Current State and Development Prospects - II”, held with the financial support of RFBR (project № 20-0922004) and partial support of the Russian Government Grant (№ 075-15-2019-1879).

For citation: Gongmujafu (Gombojav). Tradition and Symbolism of Sheep Scapula Divination: a Case Study of Bayangol Mongols from Xinjiang. Mongolian Studies (Elista). 2020. Vol. 12. No. 3. Pp. 446-454. (In Mong.). DOI: 10.22162/2500-1523-2020-3-446-454

\section{Оршил}

Ер нь монголчууд «малын дотор мах эрдэнэ, махан дотор яс эрдэнэ...» гэж хэлдэг юм. Яс (дал, хэлдэг яс) шинждэг энэ нэг зан үйл нь зөвхөн монголчуудын үйл амьдралд л илүү шиг харагдах болно. Энэ нь яриангүй, мал аж ахуйн хэлбэрээр амьдралын арга маягаа болгосон малжил амьдралын зан заншилтай нягт холбоотой гэж үзэж болно. Ялангуяа, ойрад монголчуудын дотор ясны тухай хүндэтгэл журам, цээр хорио маш олон байдаг. 
Дал шинждэг энэхүү ёс заншил нь чухам аль үед үүсэн хөгжсөнийг бодитойгоор хэлж дийлэхгүй боловч Чингис хааны цаг үед дал шинжих, далны төлгө нэгэнтээ маш өргөн хэвчээгээр дэлгэрч байсан гэдгийг «Юань улсын түҮх», «Илюй Цүйцаагийн намтар», «Хар татаарын тухай хэргийн товч» гэх мэтийн арвин олон түүхэн сурвалжаас олж мэдэж болох юм.

Хамгийн наад захдаа монгол үндэстний уран зохиолын гурван оргилын нэгэн болсон «Жангар»-ын туульд Жангарын баатрыг дүрслэхдээ «далаараа далан тохой» гэх ба Жангарын баатар мангасын ордонд орох үеийн байдлыг «далан давхар үүдийг далныхаа гэрэлд хүргэлгүй ардаа хаяж ороод» гэж дүрсэлсэн дүрслэл олонтоо илэрдэг [Жаңһр 1978].

Үүнээс ч гэсэн бид далны тухай шүтлэг бишрэл монголчуудын дунд аль эртнээс эхлэн өөрийн байр суурь, нөлөө тусгалаа олсон гэдгийг ойлгон мэдэж болох юм.

\section{Далыг хүндэтгэдэг болсон домгийн тухай}

Гагц ойрад монгол гэлтгүй бүх монголчуудын зан үйлд ууц толгой, өвчүҮ сүүж, дал нуруу, шагаа чөмөг, богт чөмөг гэх мэтийн мах идээ нь хүндэтгэл идээнд тоочигдон ах ихэс, ахмад настайчууд буюу ноён сайд гэх мэтийн хүндэт зочин, төрөл садан, эрхэм тушаалтан нарыг хүндлэн дээдэлж, зочлон дайлахдаа эдгээр хүндэтгэл (ойрадчууд яам тавих гэдэг) идээг заавал гаргаж, тэд нарыг хүндлэн дээдэлж байгаа халуун дотно хайр сэтгэлээ илтгэдэг. Ялангуяа, ойрадчууд далыг их хүндэтгэдэг болохоор хүндэтгэлийн дагуу цээрлэл журам ч бас аяндаа дагалдан оршдог.

Жишээлбэл: далыг бага хүүхдэд бариулдаггүй мөртөө далыг шүдээр мөлжиж болохгүй, зээ хүнд дал бариулдаггүй, нагац нар үгүйрнэ гэдэг. Бас далыг дутуу мөлжвөл малын хишиг харина гэх буюу ясыг нь сайн мөлжвөл мал хойд төрөл түргэн олно гэж заавал ясыг цэвэр мөлжихийг шаарддаг юм. Үүнээс гадна бас яс сайн мөлжвөл гарсан хүүхэд сайхан өнгөлөг болно гэж хэлэлцдэг. Энэ нь үнэн худлыг сайн мэдэхгүй, гэвч юу ч гэсэн яс сайн мөлжихийг хичээсэн хэллэг байна.

Далыг гийчдэд тавихдаа хамгийн өндөр настай хүний өмнө тавина. Ингээд настай хүн даланд гар хүрэхээс өмнө өөр хүмүүс гар хүрч болохгүй. Далны махыг ганцаараа идэж болохгүй харин «далны махыг даяараа идэж, далдхан үгээ ил хүүрнэе» гэж хүн бүхэнд далны махыг амсуулдаг. Далыг сайн мөлжсөний дараа хормойг нь заавал сэтэлж хаях хэрэгтэй. Юуны учраас ингэж хийх болсон тухай би багадаа ааваасаа сонсож байсан Галдамба баатартай холбогдсон нэгэн сайхан домог байдаг. Энэ домог С. Базарын «Ойрад монголчуудын дал шинжлэх ба шавдах тухай» гэсэн өгүүлэлд бичсэн тэр домогтой адилхан учраас энд дахин нуршихгүй [Баазар 1991: 80].

Далны ясыг шавдаж (хормойг нь сэтэлж) хаях болсон тухай өөр бас нэг хэллэг байдаг байна. Юу гэвэл, эрт дээд үеэс аваад монгол хүн далны ясыг шатааж, бэлгэ төлгө үздэг заншилтай тул далны хормойг шуучиж хаявал бусад хүн тэр далаар бэлгэ төлгө татаж, хаясан хүний байдлыг мэдэж чадахгүй гэж үздэгээс далны ясыг хаяхдаа эрхбиш хормойг нь шуучиж хаях болсон юм гэнэ [Намжил 2010: 355] . 


\section{Этнология и антропология}

Гэтэл далаар төлгө үзэх ба дал шинжих (шинжлэх) гэдэг бол бүрмөсөн адил бус хоёр зүйлийн агуулгатай үйл хэрэг болох юм. Төлгө үзэх гэдэг бол ямар нэгэн хэрэг учрын сайн муу болох, үйл хэрэг бүтэх эсэх, эсвэл ямар нэгэн золби алдуул алдаж түүнийгээ олдох эсэхийн тухай магадлаж төлгө барьдаг байхад дал шинжих гэдэг нь харин энэ нэг айл, хошуу сум гэхчилэн бүх нутаг нурууны хийморь нь мандаж, хишиг буян нь дэлгэрч, өнөр баян өлзий дэмбэрэлтэй болох гэх мэтийн ирээдүйн сайн сайхныг хүсэн ерөөж, зөгнөн бэлэгшээсэн агуулгатай байдаг.

\section{Дал шинждэг үг хэллэгийн тухай}

Ойрад монголчууд далыг дээд яамаар үзэж, хүндэт гийчнийг зочилж дайлахдаа заавал гаргадаг гэж дээр нэгэнт ярьсан билээ. Тэгвэл одоо түүнийг шинжин хэлдэг үг хэллэгийн талаар нарийвчлан өгүүлье. Далыг шинжихэд омгийг нь хоёр хуваан шинждэг. Даруй гэрийн эзний омог ба мал сүргийн омог гэж хоёр ангилан шинжинэ.

Хонины далны толгойн доод хэсгийн хүзүүний өмнө талаас өмнөш гарсан шовгор ясыг 'далны омог’ (даруй гэрийн эзний омог) гэдэг.

Үүнийг:

Харийн дайсанд дарагддаггүй

Хатуу үйлд нугардаггуй

Өрх гэрийн хийморь мандаж

Эр залуугийн омог нь бадардаг байна — гэж шинжин хэлдэг [Цэрэнжав, Үзэмэ 2008: 186].

Хонины далны омгийг дагасан нарийхан зооны баруун талын ирмэгийг 'мальын омог' гэнэ. ТэрхүҮ ирмэг нь дотогш матийгаад хумсанд өлгөгдөж дорхуйц болбол их сайн гэж үзээд:

Буман малын буянтай

Түмэн мальен хишигтэй

Тоо бүрэн толгой мэнд

Үржиж өсөх өлзий дэмбэрэлтэй байна — гэж шинждэг [Цэрэнжав, Үзэмэ 2008: $186]$.

Хонины далны толгой дээрх хотгорыг 'алтан хайсан' гэдэг. Энэ хотгор нь хэдий гүн бол төдий сайн гэж бэлэгшээдэг.

Үүнийг:

Хүрэл алтан хайсанд нь хишгээр дҮҮрэн

ХөвгуҮн ХүҮхэнд нь инээдээр дүҮрэн

Өөх тосоор бялхаад байдаг

Өөдрөг сайхан айл болдог байна — гэж шинждэг [Цэрэнжав, Үзэмэ 2008: 186].

Хонины далны омгийн (омгийг багтаасан тэр хэсэг) сэрвээг гэрэлд хандуулж үзээд:

БэрээчҮҮдийн хөл хүнд

Бэлгэ дэмбэрэлтэй сайхан байна.

Агуу үйлсийг бүтээдэг

Ариун цагаан хүҮхэд төрдөг байна — гэж шинждэг [Цэрэнжав, Үзэмэ 2008: 186]. 
Хонины далны омог буюу сайн агтын 300 гэдгийн баруун талын өргөн хавтгай ясны далны толгой талыг нь далны гэрэл гэж, хормой талынхыг нь 'алтан хот' гэнэ. Хормой тал нь хэдий өргөн уужим болбол төдий сайн гэж бэлэгшээдэг.

Тэгээд ҮҮнийг:

Алтан хот нь уужим байна.

Адуу мал нь өсөх иинжтэй.

Ард түмэн нь тайвуу

Амран жаргадаг шинжтэй байна — гэж шинждэг [Цэрэнжав, Үзэмэ 2008: 187].

Хонины далны толгойн доод хэсгийн нарийн сагалдаргыг 'алтан хүзYY' гэнэ. Энэ хэсэг нь бүдүүн болбол бат бөхийн бэлгэ тэмдэг гэж үзээд:

Тэнхээтэй эрийн чадльг шалгахад

Тэмдэглэж шалгарсан баруун дал байна.

Долоон эрийн дунд хурууг

Тэсэж өнгөрүҮлж чаддаг бат бэх хүзуүн жиги — гэж шинжилдэг юм [Цэрэнжав, Үзэмэ 2008: 187].

Хонины далны омог буюу ‘сайн агтын зоо’ гэдгийн зүүн талын нарийвтар урт хавтгай ясыг ‘алтан хүрээ’ буюу 'алтан онгои’ гэдэг бөгөөд далны дундах зоогийн зүүн биеийн гадна талд байдаг болохоор нутгийн хил хязгаар гэж Үздэг. Тэгээд тэр хэсгийг

Алтан хүрээ нь мөнх сайхан хүрээ жий,

Амар төвшний баталгаа болсон хүрээ байна.

Айл аймаг тайван төвшин суух,

Өлзий сайтай алтан хүрээ байна - гэж шинжилдэг юм [Цэрэнжав, Үзэмэ 2008: 187].

Далны ясны баруун хавиргын ирмэг дээрх өөрөөр хэлбэл, 'алтан хот' хэмээгчийн гадар талын ирмэг дээрх ховил татсан зурааг 'ияадан зам' гэдэг. Зарим газарт адууны зэл буюу хурдан морины зам ч гэдэг. Энэ хэсэг нь зузаан болбол сайн гэж үзээд:

Сайн цуагаан хаалга нь урт жиги

Санасан үйл нь саадгүй бүтэх юм байна

Сунасан иагаан хаалганд нь хари саадгуй жиги

Сайжрах үйлд нь өөжрөх өлзий хутаг тогтож байна — гэж шинжилдэг юм

[Цэрэнжав, Үзэмэ 2008: 187].

Далны омгоос доош, хутганы мөрийн төдий тэрхүу нарийхан зоог 'сайн aгmblн зоо’ гэдэг. Энэ хэсэг нь тэгш өргөн болбол сайн гэж шинжлээд:

Бугын иинж бүрдсэн сайн агтын зоо байна.

Салхинаас хурдан сайн хүлэг гарах иинжтэй.

Хөөснөө гүйиэж, хөөгдсөндөө гүйиэгддэггүй.

Хэзээ мөнхөд нэр төртэй айл болох ерөөлтэй жиги — гэж шинжилдэг юм

[Цэрэнжав, Үзэмэ 2008: 187] .

Далны хормойг нь гараараа барьж үзээд:

Хормой ч өргөн байна

Хормой дҮҮрэн хөвгуҮд хүҮхэдтэй. 


\section{Этнология и антропология}

Хотоор дүүрэн мал хараатай.

Хотол төгс амгалан эдлэх юм байна — гэж шинжилдэг [Цэрэнжав, Үзэмэ 2008: $188]$.

Далны ар талын тэвш нурууг ‘уудам бэлчээр өргөн шил’ гэдэг. Тэр нь хэдий өргөн уудам болох тутам төдий сайн гэж:

Ар биеэр нь нутагласан бүхэн айраг изэээгээр бялхаад байдаг.

Өмнө биеэр нь өвөлжсөн бүхэн өөх тосоор халгиад байдаг.

Зүүн биеэр нь зуссан бүхэн зол жаргалаар иэнгээд байдаг.

Баруун биеэр нь байрласан бүхэн бяслаг хоормогоор бялхаад байдаг.

Хонь иддэг хонгорзултай, ямаа иддэг ядаар шарилжтай,

Үхэр иддэг өлөн түнхтэй, адуу иддэг атгар шар бэтэгтэй,

Тэмээ иддэг тэсгэнэ таартай,

Өн иимлэг бэлчээртэй өргөн их хөдөө байна — гэж шинжилдэг юм [Цэрэнжав, Үзэмэ 2008: 188].

Тэгээд далыг шинжилж бараад эзэнд нь өгч ерөөлгөдөг. Эзэн нь далыг тосож аваад:

Идсэн мах нь рамаан болж,

Ижил нь мянга түм хүрч,

Ирсэн бүгдийн хийморь нь мандаж,

Хишиг буян дэлгэрч,

Хотол дүүс амгалан эдлэх болтугай! — гэж ерөөл тавьдаг [Цэрэнжав, Үзэмэ 2008: 188].

Энэ болбол дал шинждэг үг хэллэг болно. Гэтэл нутаг нутгийн зан заншил харилцан адилгүй учраас бага сага адил бус ялгаа зөрөө орших нь яриангүй. Энэ нь бас аман уламжлагчийн хэл хэллэгийн хэв намбатай бас нягт холбоотой. Гэхдээ үндсэн агуулга, зөн бэлгэдэл нь адилавтар байх болно.

\section{Далны бэлгэдэл шинжийн тухай}

Дээр нэгэнтээ дал шинжихэд хэлдэг үг хэллэгийн тухай тоочлоо. Одоо түүнд агуулагдаж байгаа бэлгэдэл шинжийн тухай өгүүлье. Түүний бэлгэдэл шинжийг хураангуйлбал:

1. 'Алтан хайсан'-ы шинжлэлээс үзэхэд, энэ айлын өөдрөг сайхан аж амьдралыг бэлгэдсэн шинжтэй. Чухам болбол энэ айл хайс тоогоодоо элбэг, ирсэн гийчин нь идээ цэгээгээр бялхаж, хоносон гийч нь хорго өөхөөр бялхаад байдаг өгөөмөрч сайхан айл өрх болохыг бэлэгшээсэн байдаг.

Монголчууд ердөө ч их өргөн уужим сэтгэлтэй өгөөмөрч сайхан зантай байдаг. Тиймээс харамч байж болохгүй, харамлаад байвал «харамчийн там (бэрдийн там)-д унана» гэж хичээдэг юм.

2. 'Далны омог' (даруй гэрийн эзний омог)-ийн шинжлэлээр эр хүн бол энэ нэг гэр бүлийн түшиг тулгуур болохоор өнө үүрд эрэлхэг баатарлаг цөс зоригтой, зааснаа авдаг, зорьсноо биелүүлдэг, «хугарахаас биш нугаршгүй» эрч зориг, эрс хатуу эр хүн болохыг зөгнөн бэлэгшээсэн юм.

3. 'Малын омог'-ийн шинжлэлээр энэ айл хойшдоо үргэлжид их мал сүрэгтэй, өрнөсөн сайхан аж амьдралтай өнөр баян айл өрх болохыг зөгнөн бэлэгшээсэн байна.

4. 'Далны сэрвээ’-ний шинжлэлээр олон сайхан үр хүүхэдтэй болж, үе удам угсаа үндэстнээ уламжлан залгамжилж, хөгжин мандахыг зөгнөн бэлэгшээсэн 
юм. Дэлхийн аль ч үндэстэн гэсэн ‘бэлбэсэн’ болохыг их дургүйцдаг. Тиймээс хүүхэд гаргах бол хамгийн бэлгэ дэмбэрэлтэй гэж үздэг. Үүний тухай монголчуудын дотор бас арвин олон цээр хорио, хүндэтгэл журам байдаг. Бас нэгэн болбол дээр үед тухайн нийгмийн нөхцөл шалтгаанаас болж олон хүүхэд төрүүлэх бол улам сайн гэх мөртөө ялангуяа хүҮ гаргах бол хамгийн сайн гэж үздэг байв.

5. 'Алтан хот'-ын шинжлэлээс үзэхэд бас л адуу мал, эд хөрөнге элбэг дэлбэг болохыг бэлэгшээсэн шинжтэй шиг, гэтэл үүнд «алтан хот нь уужим байна» гэдэг энэ нэг үгээр дамжуулж, эд хөрөнгийг голчилсон бус, харин өргөн уудам нутаг дэвсгэртэй болж, уужим тайвуу аж төрж амьдран суухыг бэлэгшээсэн юм. Монголчууд «уусан ус рашаан, унасан шороо алт» гэж нутаг усыг маш дээдлэн шүтэж хайрлан хамгаалдаг ба «миний нутгийн газар шорооноос бурхан гуйсан ч битгий өг» гэсэн сургаал байдаг. Энэ нь үндэстний амьдрал ахуйн нөхцөл шалтгаантай шууд холбоотой гэж хэлж болмоор.

6. 'Алтан $\chi_{Y} Y Y$ '-ний шинжлэлээр дамжуулж, агуу их хүч чадалтай баатар идтэн болохыг зөгнөн бэлэгшээсэн. Бас нэг талаар тус айлын үйлс амьдрал нь бат бэх болох, өөрөөр хэлбэл, «эд нь хүүрэг болж, эзэн нь мөнх болж, суурь нь бат болж, сүлжил нь олон болж» насан туршид хамт зол жаргалтай сайн сайхан амьдрахыг бэлэгшээсэн юм.

7. 'Алтан хүрээ '-ний шинжлэлээс энэ нэг айл аймаг, нутаг нуруун бүгдээрээ энх тайван, эрүүл бүтэн, дайн дажингүй, зовлон зүдүүргүй байхыг бэлэгшээсэн байна.

8. 'Цагаан зам’ буюу 'хурдан морины зэл (зам)' гэдгийн энэ шинжлэлээс бид тус нэг айлын хойшдын амьдралын зам нь ас шулуун, саад тотгоргүй, урагштай сайхан амьдрахыг бэлэгшээсэн байна.

9. 'Сайн агтын зоо'-ны шинжлэлээр ямар ямар сайн агт гарах шинжтэй гэдгээр дамжуулж, энэ айл хэзээ мөнхөд нутаг нуруундаа хүндтэй, нэр нөлөөтэй, олондоо таашаагдсан, нутаг олныхоо хайр хүрээллийг татсан сайн сайхан айл өрх болохыг зөгнөн бэлэгшээсэн юм. Үүнд 'буга' болон 'морь' нь тус шинжлэлд хамгийн гол тодотгол болсон байдаг. Морь болбол монголчуудын эрдэнэ хүлэг байж, буга болбол газар усны навтаг савдгийн хүлэг унаа гэж үздэг. Тиймээс энэ хоёр зүйлийн амьтнаар оруулж шинжилж байгаа нь түүнийг хайрлаж хүндэлж, биширч шүтэхээр дамжуулан энэ нэг айл өрх бас нутаг нуруундаа тийм сайхан нэр хүндтэй болохыг зөгнөн бэлэгшээсэн юм.

10. 'Далны хормой'-г шинжлэхээр дамжаад энэ нэг айл өрх, нутаг нурууны бүх хотол дүүс, амгалан эдлэхийг бэлэгшээсэн юм.

11. 'Уудам бэлчээр өргөн шил'-ийн шинжлэлээр ирж, өмнө нь энэ нэг гагц айл өрхөөр гол болгон зөгнөн ерөөж байсан бол одоо харин бүх нутаг нуруун цөмдөө элбэг дэлбэг эд хөрөнгөтэй, үгүйрдэггүй баян, үхэлгүй мөнхөд, үргэлж жаргал цэнгэлээр бялхан цэнгэж байхыг зөгнөн бэлэгшээсэн байна.

Дээрхийг хураангуйлбал, нэг талаар хэдийгээр хэдхэн мөр үгээр шинжлэн хэлж байгаа боловч агуулга нь маш гүн, алс хол ирээдүйн сайн сайхныг бэлэгшээж байгаа болно. Нөгөө талаар, үгийн өнгөн тал дээр нэг зүйлийн бэлгэдлийн өнгө байх мөртөө түүний цаана бас хэд хэдэн зүйлийн бэлгэдлийн агуулга давхар нуугдаж байгааг олж мэдэж болно. 


\section{Этнология и антропология}

\section{Дал шинжилгээнд илэрсэн хэдэн онцлог}

Дээрх далны шинжилгээнд илэрсэн хэдэн онцлогийн тухай өөрийн боловсронгуй бус хэдэн ойлголтоо өгүүлье.

1. 'Алтан' гэх үгийг олон дахин хэрэглэсэн байна. Жишээлбэл: 'алтан хүрээ’, ‘алтан хайсан', ‘алтан хүзYY', 'алтан хот' гэх мэтээр 'алт' гэх үгийг тодотгол болгон хэрэглэсэн нь олон илэрч байна. Энэ нь юунаас болсон бэ гэвэл,

— эртний үед алт, мөнгө монгол нутагт маш их хэмжээгээр хэрэглэгдэж байсан. Алт мөнгө нь өнөөдрийн цаасан зоосны хэрэгцээг хангаж байсан гэж хэлж болох юм. Ямар нэгэн сайд ноёдод бэлэг дурсгал өгөхдөө хэчнээн алтан ембүү өгч байсан гэх мэтийн сураг зангийг зарим түүхэн тэмдэглэлээс олж харж болно. Дээр үед алтыг тэмээгээр ачдаг байлаа гэж настайчууд бас хуучилдаг юм. Тиймээс алт бол монголчуудын амьдрал дунд дутагдаж болшгүй солилцооны эд хэрэглэгдэхүүн болж байсан учраас алтыг маш хүндэтгэж үздэг байсан байлтай.

- настайчууд одоо ч гэсэн «алтан шуухан (шиг) гэрэлтэй болж, мөнгөн шуухан хүндтэй болж» гэж ерөөл тавьдаг. Алт бол гэрэлтэй учраас хээр гадна явахад биедээ зүүгээд явбал сайн байж, биед муу юм (сүр сүлдэр, шулам чөтгөр гэх мэт) халдаж чадахгүй гэж настайчууд ярьдаг. Иймээс 'aлm' гэсэн үгийг бэлэгшээж олон хэрэглэсэн бололтой .

2. Далны ясны ямар нэг хэсэг нь бүр хэдий 'өргөн', 'mэгш', 'бүдүYн', 'зузаан', 'гүн' болбол төдий сайн гэж бэлэгшээдэг байна. Харин «нарийн буюу нимгэн» болбол сайн гэж гараагүй. Монголчууд аль эртнээс аваад өргөн их тал нутагт өгөөмөр сайхан сэтгэлээрээ өөрийн дураар амьдарч ирсэн учраас ямар ч юманд бүр элбэг дэлбэг, бялхам дүүрэн байдаг. Энэ нь үндэстний амьдралын орчин ахуй, санаа сэтгэлгээтэй нягт холбоотой гэж үзэж болох юм.

3. Дал шинжих үгээс үзэхэд бүр «ийм болдог байна, тийм болдог байна» гэсэн таамаглалын шинжтэй шиг. Гэтэл үнэндээ жинхэнэ тэгж таамаглан мэдчихсэн биш, харин ирээдүйд тийм сайн сайхан болох болтугай гэсэн хүсэл эрмэлзлээ зөгнөн бэлэгшээж байгаагийн илрэл юм.

\section{Ном зуй}

Баазар 1991 - Баазар С. Ойирад моңһлчуудин дал шинжлх ба шабдах тухай (= Обряд гадания и надламывания лопаточной кости у ойратов) // Хаан Теңгер. № 4. 1990. C. 80-98.

Жаңһp 1978 - Жаңһр: Хальмг баатрлг дуулвр (25 бөлгин текст) / сост. А. Ш. Кичиков, ред. Г. И. Михайлов. М.: Наука, ГРВЛ, 1978. Т. 1. 441 с.; Т. 2. 417 с.

Намжил 2010 - Намжил Т. Ойрад монголын зан үйлийн соёл оюуны амьдралын боть (= Традиция и культура ойратов). Үрүмч (= Урумчи): Шинжааны ардын хэвлэлийн хороо (= Народное издательство Синьцзяна), 2010. 367 с.

Цэрэнжав, Үзэмэ 2008 - Цэрэнжав Д., Үзэмэ На. Харшарын монголчуудын зан үйл (=Традиции и обряды карашарских ойратов). Үрүмч (= Урумчи): Шинжааны ардын хэвлэлийн хороо (= Народное издательство Синьцзяна), 2008. 435 с.

\section{References}

Baazar S. Scapula fracture and divination rites among the Oirats. Khaan Tengger. 1990. No. 4. Pp. 80-98. (In Mong.) 
Kichikov A. Sh. (comp.), Mikhailov G. I. (ed.) The Jangar: Kalmyk Heroic Epic (Texts of 25 Songs). Moscow: Nauka, 1978. Vol. 1. 441 p.; Vol. 2. 417 p. (In Kalm.)

Namjil T. Tradition and Culture in the Life of Oirats. Urumqi: Xinjiang People's Publ. House, 2010. 367 p. (In Mong.)

Tserenjav D., Üzeme Na. Traditions and Rituals of Karashar Oirats. Urumqi: Xinjiang People's Publ. House, 2008. 435 p. (In Mong.)

Baazar S. [Rite of divination and fracture of the scapula in the Oirats]. Haan Tengger. № 4. 1990. Pp. 80-98.

[Dzhangar: Kalmyk heroic epic (Lyrics of 25 songs)] / compil. by A. Sh. Kichikov, ed. by G. I. Mikhailov. M.: Nauka, 1978. Vol. 1. 441 p.; Vol. 2. 417 p.

Namzhil T. [Tradition and culture in the life of the Oirats]. Urumchi: People's Publ. House of Xinjiang, 2010. $367 \mathrm{p}$.

Tserenzhav D., Yzeme Na. [Traditions and rituals of the Karashar Oirats]. Urumchi: People's Publ. House of Xinjiang, 2008. 435 p. 